\title{
BUSSINESS ANALYSIS OF CASSAPRO UTILIZATION IN FEED ON KAMPONG CHICKEN IN MEDAN
}

\author{
D A Lumbangaol, A H Daulay, I Sembiring, T H Wahyuni, N Ginting \\ Animal Production Program, Faculty of Agriculture, Universitas Sumatera Utara, \\ Medan 20155 \\ E-mail: dennylgaol@gmail.com
}

\begin{abstract}
This study aims to determine the feasibility and efficiency of the economic value of the business of raising livestock chicken with cassapro utilization in diet at various levels in chicken age 0-12 week. Research was held at Medan city in December 2015 to March 2016. Research using a survey method to determine the price of feed used in research. Cassapro flour consists of level 0\% (P0), 10\% (P1), 20\% (P2), 30\% (P3), 40\% (P4). Parameters observed that the total cost of production, income, analysis of profit / loss, Revenue / Cost ratio ( $\mathrm{R} / \mathrm{C}$ ratio) and Income Over Feed Cost (IOFC) for a period of 3 months.

The results showed that the average income $(\mathrm{Rp} / 100 \mathrm{head} / 3$ month) were the highest in treatment P3 $(279,468.89)$ and the lowest profit in treatment P0 $(234,395.64)$, the average $\mathrm{R} / \mathrm{C}$ ratio was the highest in treatment P3 (1.44) and the lowest in treatment P0 (1.34), the average IOFC for 3 months were highest in treatment P3 (196.123) and the lowest in treatment P1 (136.401). The conclusion from this study indicate cassapro as a mixture of feed ingredients in ration to the level of $40 \%$ can provide benefits feasibility applied to the community.
\end{abstract}

\section{Introduction}

Feed has the highest cost in the husbandry business which is about $70 \%$ of total cost, including kampong chicken husbandry business. The limited feed component availability compared to the human and livestock population give raise to import activity of feed component in Indonesia especially corn. With that condition in mind, author was inspired to search for an alternative feed component that domestically produced and available in large quantity which is cassapro. Cassapro is a abbreviation from cassava and protein, which is made by fermentating cassava in aspergillus niger solution. Cassapro has the nutritional values on par with corn and soya beans, especially in protein and carbohydrate. The process of making cassapro is not too difficult for farmers to apply, on account of the availability of aspergillus niger which is abundant in the farmers surrounding.

Bussiness analysis is an important part to determine whether or not cassapro has the market value on par with corn which as we know have a good market value (as in cost and nutritional value). Business analysis is used also but not limited to determine problems, solution and prevention in husbandry business.

\section{Materials and Methods}

This research was conducted by collecting data from 9 (nine) sub districts in Medan North Sumatra province, in December 2015 to March 2016.

The method used was a survey by direct interviews with respondents who were guided by a questionnaire.[2]

The research area was determined by purposive, the sample selection started on the personal judgment of researchers who claimed that the selected sample truly representated [3]

2.1. Data analysis 
Descriptive Analysis

Descriptive analysis used to analysis data using direct observation on research object to discover situation, location, business model and characteristics of kampong chicken farm.

Economic Analysis

Economic or quantity analysis used to calculate:
a. Total Cost $=$ Fixed Cost + Varied Cost
b. Total Revenue $=($ meat price $/ \mathrm{kg}$ x production grade $)+($ byproducts price $\mathrm{x}$ production grade)
c. Profit $=$ Total Revenue - Total Cost
d. $\mathrm{R} / \mathrm{C}$ ratio $=$ Revenue $/$ Cost; to determine whether or not the business is profitable
e. Break Even Point Price : Total Cost / Production Result
f. Break Even Point Product : Total Cost / Market Price

IOFC (Income Over Feed Cost)

IOFC is used to determine the profit of a business compared to feed cost: Total Revenue Total Feed Cost

\section{Results and Discussion}

\subsection{Cassapro research result}

Table 1. Production Cost, Revenue and Result from using cassapro as a feed component alternative

\begin{tabular}{lrrrrr}
\hline \multirow{2}{*}{ PARAMETER } & \multicolumn{5}{c}{ TREATMENT } \\
\cline { 2 - 6 } & \multicolumn{1}{c}{ T0 } & \multicolumn{1}{c}{ T1 } & \multicolumn{1}{c}{ T2 } & \multicolumn{1}{c}{ T3 } & \multicolumn{1}{c}{ T4 } \\
\hline Fledgling Cost (Rp) & 140.000 & 140.000 & 140.000 & 140.000 & 140.000 \\
Feed Cost (Rp) & $69.589,06$ & $65.936,85$ & $62.319,87$ & $58.579,51$ & $55.155,87$ \\
Medicinal Cost (Rp) & 16.000 & 16.000 & 16.000 & 16.000 & 16.000 \\
Coop Equipment Cost (Rp) & 20.000 & 20.000 & 20.000 & 20.000 & 20.000 \\
Coop Rental Cost (Rp) & 60.000 & 60.000 & 60.000 & 60.000 & 60.000 \\
Transportation Cost Rp) & 40.000 & 40.000 & 40.000 & 40.000 & 40.000 \\
Workers Cost (Rp) & 80.000 & 80.000 & 80.000 & 80.000 & 80.000 \\
Total Production Cost (Rp) & 425.589 & 421.937 & 418.320 & 414.580 & 411.156 \\
\hline Sales Result : & \multicolumn{5}{c}{} \\
\hline Kampong Chicken Sales (Rp) & 900.000 & 900.000 & 900.000 & 900.000 & 900.000 \\
Total Production Result (Rp) & 916.000 & 916.000 & 916.000 & 916.000 & 916.000 \\
Profit - Loss (Rp) & 490.411 & 494.063 & 497.680 & 501.420 & 504.844 \\
R / C & 2,15 & 2,17 & 2,19 & 2,21 & 2,23 \\
IOFC & 846.411 & 850.063 & 853.680 & 857.420 & 860.844 \\
\hline
\end{tabular}

From table 1 we can conclude that $40 \%$ treatment of cassapro were more efficient than other treatment levels. This was caused by the lowest feed price of T4 (Rp 55.155,87) compared to other treatment.

The summary of conducted research in 9 sub-districts of Medan can be seen from the table below:

Table 2. Survey data summary of farmers in Medan during research (Rp/20 chick) 


\begin{tabular}{|c|c|c|c|c|c|}
\hline No & $\begin{array}{l}\text { Total Production } \\
\text { Cost }(\mathrm{Rp})\end{array}$ & $\begin{array}{c}\text { Total } \\
\text { Production } \\
\text { Result (Rp) }\end{array}$ & $\begin{array}{l}\text { Profit/Loss } \\
\text { (Rp) }\end{array}$ & $\mathrm{R} / \mathrm{C}$ & IOFC (Rp) \\
\hline 1 & 667.000 & 900.000 & 233.000 & 1,35 & 468.000 \\
\hline 2 & 637.000 & 900.000 & 263.000 & 1,41 & 468.000 \\
\hline 3 & 657.000 & 900.000 & 243.000 & 1,37 & 468.000 \\
\hline 4 & 657.000 & 900.000 & 243.000 & 1,37 & 468.000 \\
\hline 5 & 652.000 & 900.000 & 248.000 & 1,38 & 468.000 \\
\hline 6 & 657.000 & 900.000 & 243.000 & 1,37 & 468.000 \\
\hline 7 & 667.000 & 900.000 & 233.000 & 1,35 & 468.000 \\
\hline 8 & 661.000 & 900.000 & 239.000 & 1,36 & 468.000 \\
\hline 9 & 668.333 & 900.000 & 231.667 & 1,35 & 450.000 \\
\hline 10 & 666.667 & 900.000 & 233.333 & 1,35 & 450.000 \\
\hline 11 & 683.333 & 900.000 & 216.667 & 1,32 & 450.000 \\
\hline 12 & 601.667 & 900.000 & 298.333 & 1,50 & 540.000 \\
\hline 13 & 674.167 & 900.000 & 225.833 & 1,33 & 450.000 \\
\hline 14 & 668.333 & 900.000 & 231.667 & 1,35 & 450.000 \\
\hline 15 & 670.833 & 900.000 & 229.167 & 1,34 & 450.000 \\
\hline 16 & 628.000 & 900.000 & 272.000 & 1,43 & 468.000 \\
\hline 17 & 585.600 & 900.000 & 314.400 & 1,54 & 554.400 \\
\hline 18 & 650.000 & 900.000 & 250.000 & 1,38 & 468.000 \\
\hline 19 & 646.154 & 900.000 & 253.846 & 1,39 & 484.615 \\
\hline 20 & 615.556 & 900.000 & 284.444 & 1,46 & 500.000 \\
\hline 21 & 627.778 & 900.000 & 272.222 & 1,43 & 500.000 \\
\hline 22 & 595.357 & 900.000 & 304.643 & 1,51 & 514.286 \\
\hline 23 & 614.286 & 900.000 & 285.714 & 1,47 & 514.286 \\
\hline 24 & 666.207 & 900.000 & 233.793 & 1,35 & 453.103 \\
\hline 25 & 652.000 & 900.000 & 248.000 & 1,38 & 468.000 \\
\hline 26 & 652.000 & 900.000 & 248.000 & 1,38 & 468.000 \\
\hline 27 & 624.667 & 900.000 & 275.333 & 1,44 & 468.000 \\
\hline Total & 17.445 .937 & 24.300 .000 & 6.854 .063 & 37,67 & 12.844 .690 \\
\hline Average & $646.145,82$ & 900.000 & $253.854,19$ & 1,40 & 475729,27 \\
\hline
\end{tabular}

\subsection{Total production cost}

Based on table 2, kampong chicken farms in Medan have 100 - 150 livestocks but averaged to 20 heads. Table 2 showed that the highest Total Production Cost was found on the $11^{\text {th }}$. It is caused by the consumption of feed of the $11^{\text {th }}$ was larger than the other. When consumption becomes higher with the same feed price, the total production cost will rise in response.

\subsection{Total production result}

Table 2 showed that kampong chicken farms in Medan have 100 to 150 heads, but averaged to 20 heads. Total production result from survey showed the same values, because of the averaged total of livestocks in each farm. The element that was influencing revenue was sales volume and sales prices.

\subsection{Profit/loss}


Profit/loss analysis used to determine the profitability of a farm by calculating the difference of total revenue and total cost. Based on table 2, the most profitable farm was the $17^{\text {th }}$ (Rp. 314.400) and the lowest profitable farm was the $11^{\text {th }}(\mathrm{Rp} .216 .667)$. These result can determine the continuation of a farm especially in management decision to change the commodity of livestocks, the product or any other variable that inflicted a financial loss

\section{5 $\mathrm{R} / \mathrm{C}$ ratio}

Based on the conducted survey on farmers in Medan (table 2), the $17^{\text {th }}$ have the highest $\mathrm{R} / \mathrm{C}$ ratio $(1,54)$; and the $11^{\text {th }}$ have the lowest $(1,32)$. Based on the standard, if $\mathrm{R} / \mathrm{C}$ ratio $>1$, then the farm can bring benefits to farmers. As the R/C values becomes higher, the benefit from the farm also becomes higher. As the $\mathrm{R} / \mathrm{C}$ values becomes lower, then the farm is not run efficiently.

\subsection{IOFC}

Income over feed cost was the barometer to see the feed cost which is the highest cost in a husbandry business. Based on table 2 the $17^{\text {th }}$ have the highest IOFC values, and the $11^{\text {th }}$ have the lowest.

\section{Conclusions}

The research concluded that:

1. Corn can be substituted by cassapro in Kampong Chicken's feed.

2. Cassapro is economical

\subsection{Suggestion}

This study suggest to farmers to start using cassapro as an alternative to the commercialised.

\section{References :}

[1] Getscoop. 2012. Rendah, Konsumsi Protein Hewani. Accessed on http://www.getscoop.com/id/majalah/food-review-indonesia/aug-2012

[2] Daniel, M. 2013. Metode penelitian sosial ekonomi. Bumi Aksara. Jakarta.

[3] Soekartawi. 1995. Analisis usaha tani. Penerbit universitas indonesia. Jakarta. 